\title{
Angelica sinensis suppresses human lung adenocarcinoma A549 cell metastasis by regulating MMPs/TIMPs and TGF- $\beta 1$
}

\author{
MIN GAO $^{1}$, JUN-HONG ZHANG ${ }^{1}$, FU-XIANG ZHOU ${ }^{1}$, CONG-HUA XIE ${ }^{1}$, \\ GUANG HAN $^{1}$, SHENG-QUAN FANG ${ }^{2}$ and YUN-FENG ZHOU ${ }^{1}$ \\ ${ }^{1}$ Department of Radio-Chemotherapy, Zhongnan Hospital of Wuhan University, Wuhan 430071;
${ }^{2}$ Department of Gynecological Oncology, Tumor Hospital of Hubei Province, Wuhan 430079, P.R. China
}

Received August 8, 2011; Accepted October 3, 2011

DOI: $10.3892 /$ or.2011.1527

\begin{abstract}
In this study we investigated the potential effects of Angelica sinensis on the growth and metastasis in human lung adenocarcinoma A549 cells. In vitro the Cck- 8 assays showed that Angelica sinensis had weak antiproliferative effect on A549 cells only at high concentration. The cell adhesion assay showed that Angelica sinensis decreased the adhesive ability of A549 cells in a dose- and time-dependent manner. Transwell invasion and migration assay showed that Angelica sinensis reduced the invasive and migratory abilities of A549 cells in a dose-dependent manner. In vivo the animal experiments showed that Angelica sinensis suppressed lung metastasis of nude mice at high concentration. Then, we attempted to clarify the mechanisms of anti-metastatic activities of Angelica sinensis. The results showed Angelica sinensis inhibited the enzymatic activity of matrix metalloproteinase-2 (MMP-2) and matrix metalloproteinase-9 (MMP-9), it involved the down-regulation of the expressions of MMP-2 and MMP-9 at both the protein and mRNA levels, which may be associated with Angelica sinensis suppressing the expression of TGF- $\beta 1$. It also involved the increase of the tissue inhibitors of metalloproteinases TIMP-2, but TIMP-1 decreased upon incubation of A549 cells with Angelica sinensis. The results suggest that Angelica sinensis might exert anti-growth and anti-metastasis activity against lung cancer cells through the decrease of MMP-2, MMP-9, TGF- $\beta 1$ and TIMP-1 and increase of TIMP-2.
\end{abstract}

Correspondence to: Professor Yun-Feng Zhou, Department of Radio-Chemotherapy, Zhongnan Hospital of Wuhan University, Wuhan 430071, P.R. China

E-mail: yfzhouwhu@163.com

Abbreviations: MMP-2, matrix metalloproteinase-2; MMP-9, matrix metalloproteinase-9; TIMP-1, tissue inhibitors of metalloproteinases-1; TIMP-2, tissue inhibitors of metalloproteinases-2; NSCLC, non-small cell lung carcinoma; ECM, extracellular matrix; MMPs, matrix metalloproteinases; TIMPs, tissue inhibitor metalloproteinases

Key words: Angelica sinensis, metastasis, MMP-2, MMP-9, transforming growth factor $\beta$

\section{Introduction}

Non-small cell lung carcinoma (NSCLC) is currently one of the leading causes of death in China, its high mortality is attributed to early metastasis. About $70-90 \%$ patients with lung cancer need radiation therapy, and therefore, radiation lung injury is the most common complication (1). It limits the increasing of radiation dose and influences the life quality of patients or even threatens their life. Many traditional Chinese medicines have great efficacy in radiation lung injury. The root of Angelica sinensis, also known as 'Danggui' was a popular herbal medicine and widely used for many diseases in China. It has been used for more than 10 years in our hospital to treat lung fibrosis and shows good curative effect in radiation pulmonary fibrosis (2-4).

Angelica sinensis belongs to 'activating blood and dissolving stasis' kind of traditional Chinese medicine, and some researchers think this kind of medicine can promote tumor metastasis. Li et al first reported Salvia miltiorrhiza Bunge and Radix Paeoniae Rubra such as 'activating blood and dissolving stasis' traditional Chinese medicine can promote tumor metastasis, we pay high attention to it (5). Han et al found the metastasis rate of nasopharyngeal carcinoma increased to 2.67 times compare with the control after using 'activating blood and dissolving stasis' kind of traditional Chinese medicine (6). But also, there is research with the opposite conclusion (7). Therefore, the use of Angelica sinensis needs to be clarified to confirm whether it promotes or inhibits metastasis of lung cancer cells. Adenocarcinoma of the lung is more metastatic compared to squamous carcinoma. So, we chose the high metastasis ability human lung adenocarcinoma cell line A549 cells as our research object.

Metastasis of cancer cells involves multistep processes, including changed adhesion ability between the cells and the extracellular matrix (ECM) and damaged intercellular interaction. The degradation of basal membrane and ECM of primary tumor are crucial steps for tumor invasion and metastasis. Matrix metalloproteinase (MMP) family of human zinc-dependent peptidases is responsible for degradation of the ECM (8). Among the many MMPs that have been identified, MMP-2 (gelatinase-A) and MMP-9 (gelatinase-B) are thought to be key enzymes because they efficiently degrade native collagen types IV, which are the main component of 
ECM (9-12). Many studies have shown that overexpression of MMPs is correlated with the progression of lung cancer, which contributes to tumor invasion, metastasis and angiogenesis (13). The expression of either MMP-9 or MMP-2 confers a worse prognosis in early stage adenocarcinoma of the lung (14).

All members of the MMPs family can be regulated by their endogenous inhibitors, the tissue inhibitor metalloproteinases (TIMPs), which prevent the degradation of ECM by binding MMP non-covalently in a 1:1 stoichiometric complex (15-17). Therefore, MMP activity is determined by the balance of MMP and TIMP expression. At least four TIMPs (TIMP-1, TIMP-2, TIMP-3 and TIMP-4) have been identified (18). The enzymatic activity of MMP-2 and MMP-9 is blocked by TIMP-2 and TIMP-1, respectively $(19,20)$.

MMP-2 and MMP-9 can be up-regulated by TGF- $\beta$ (21). High TGF- $\beta$ activity is associated with highly aggressive and proliferative of gliomas and a poor prognosis in patients (22). TGF- $\beta$ is also one of the critical regulators in the inflammatory reaction that orchestrates the tumor microenvironment. The studies before showed Angelica sinensis indicated its clinical efficacy in treating radiation-induced pneumonitis by down-regulation of TNF- $\alpha$ and TGF- $\beta 1(23,24)$. So, Angelica sinensis have potentially the ability to inhibit MMP-2 and MMP-9 by down-regulation of TGF- $\beta 1$.

In order to define in more detail the role of Angelica sinensis in the lung cancer metastatic process, A549 lung cancer cell line was treated with Angelica sinensis and examined for the following: i) the relationship between the Angelica sinensis and the cell proliferation, adhesion, migration, and invasion ability of A549 lung cancer cells to know whether Angelica sinensis inhibited tumor growth and metastasis. ii) the impact of Angelica sinensis on MMP-2 and MM-9 regulation including of enzymatic activity, transcriptional, post-transcriptional, TIMPs and TGF- $\beta 1$, to investigate the molecular mechanisms of Angelica sinensis-mediated malignant progression of human lung carcinoma.

\section{Materials and methods}

Cell line and culture conditions. The A549 human lung adenocarcinoma cells were obtained from Typical Species Preservation Center of Wuhan University (Wuhan, China) and cultured in RPMI-1640 (Gibco/BRL) media with $10 \%$ fetal calf serum (Hangzhou Evergreen Biological Corp., China) in the presence of $5 \% \mathrm{CO}_{2}$. Angelica sinensis injection (25\%): produced by Zhongnan Hospital of Wuhan University Pharmacies, batch number 960812 . The A549 cells were treated with various concentrations (0,2.5, 10 and $25 \mathrm{mg} / \mathrm{ml})$ Angelica sinensis for $24 \mathrm{~h}$ before investigation in vitro.

Cell viability assay. The effect of Angelica sinensis on A549 cell growth was examined by the the Cell Counting Kit- 8 (CCK-8) (Dojindo Molecular Technologies, Inc., Gaithersburg, MD) assay following the manufacturer's protocol. Cells were seeded at a density of $2 \times 10^{4}$ cells/well in a 96-well plate for $24 \mathrm{~h}$. Then, the cells were treated with Angelica sinensis at various concentrations $(0,2.5,10$ and $25 \mathrm{mg} / \mathrm{ml})$ for various periods of time (12, 24, 48 and $76 \mathrm{~h})$. Each concentration was repeated six times. After the exposure period, $10 \mu \mathrm{l}$ of WST- 8 was added to each well and allowed to incubate for $3 \mathrm{~h}$. Finally, the absorbance of OD at $450 \mathrm{~nm}$ was detected and recorded with microplate reader (Rayto, RT-6000, USA). Each point was expressed at the mean $\pm \mathrm{SD}$ from three different experiments.

Cell adhesion assay. The MTT assay was performed to calculate the number of attached cells. Each well of a 96-well plate was coated with $0.1 \%$ fibronectin (Beijing University Biology Center, China). The plates were washed and incubated with $2 \%$ bovine serum albumin for $2 \mathrm{~h}$. The A549 cells $\left(4 \times 10^{4}\right)$ were treated with various concentrations Angelica sinensis $(0,2.5,10$ and $25 \mathrm{mg} / \mathrm{ml})$ for $24 \mathrm{~h}$ at $37^{\circ} \mathrm{C}$, then cells were added to each well and incubated at $0.5-, 1-$ and 2-h intervals at $37^{\circ} \mathrm{C}$. Unattached cells were removed by washing with PBS. MTT was added to each well and incubated for $4 \mathrm{~h}$ at $37^{\circ} \mathrm{C}$. Formazen crystals were dissolved by addition of DMSO solution. The absorbance of each well was determined using the microplate reader (Rayto, RT-6000) at $570 \mathrm{nM}$.

Cell invasion and migration assays. The ability of A549 cells pass through matrigel-coated filters was examined by the tranwell invasion assay. The assay was measured using transwell chambers (Corning Costar, MA) with $8-\mu \mathrm{m}$ pore size polycarbonate filter according to the manufacturer's. First, Matrigel (BD Biosciences, Bedford, MA) was applied to the top side of the polycarbonate filter. A549 cells were resuspended in serum-free medium after treating with various concentrations of Angelica sinensis $(0,2.5,10$ and $25 \mathrm{mg} / \mathrm{ml})$ for $24 \mathrm{~h}$. Medium containing 10\% FBS was applied to the lower chamber as chemoattractant, the cells $\left(2 \times 10^{4}\right.$ cells/well $)$ were seeded on the upper chamber and incubated for $16 \mathrm{~h}$ at $37^{\circ} \mathrm{C}$. At the end of incubation, the cells in the upper surface of the membrane were removed with a cotton swab and cells invaded across the matrigel to the lower surface of the membrane were fixed with methanol and stained with $0.1 \%$ Crystal violet. The cells that invaded the lower surface of the filter were quantified under a microscope (x20). Each experiment was carried out in triplicate. The migration assay was performed as described for the invasion assay, but without the coating of matrigel.

Animal assay. Nude mice (8-10 weeks old) were purchased from the Hubei Provincial Disease Control and Prevention Center and maintained in a germ-free environment in the animal facility. In the model, the highly metastatic A549 cells ( $2 \times 10^{5}$ cells) injected into the tail vein of nude mice and divided into four groups ( $\mathrm{n}=8$ each). The mice were treated with PBS (control group) or Angelica sinensis $(0.5,1$ and $5 \mathrm{mg} / \mathrm{g}$ ) p.i. (intraperitoneal injection) three times a week for 14 days. Then, the mice were sacrificed, lungs were removed, weighed and mouse lungs were injected intratracheally with India ink and fixed in Fekete's solution, the metastatic tumors in each lung were counted under a dissecting microscope. The experiments were performed three times. The experimental protocols were reviewed and approved by the Animal Research Committee of Zhongnan Hospital of Wuhan University.

Gelatin zymography. The enzymatic activity of MMP-2 and MMP-9 in the conditioned medium of A549 cells was determined by gelatin zymography. The conditioned medium was 
Table I. The primers used for quantitative real-time PCR.

\begin{tabular}{|c|c|}
\hline Gene & Primer sequences $5^{\prime} \rightarrow 3^{\prime}$ \\
\hline$\beta$-actin & $\begin{array}{l}\text { Forward: GTCCACCGCAAATGCTTCTA } \\
\text { Reverse: TGCTGTCACCTTCACCGTTC }\end{array}$ \\
\hline TGF- $\beta 1$ & $\begin{array}{l}\text { Forward: GCAGCTCCTTTAGGTTCTT } \\
\text { Reverse: TTCCTGGGCTGGGCTGGACC }\end{array}$ \\
\hline MMP-2 & $\begin{array}{l}\text { Forward: AGTGACGGAAAGATGTGGTGTG } \\
\text { Reverse: CTTGGTGTAGGTGTAAATGGGTG }\end{array}$ \\
\hline MMP-9 & $\begin{array}{l}\text { Forward: TCCCTGGAGACCTGAGAACC } \\
\text { Reverse: CGGCAAGTCTTCCGAGTAGTTT }\end{array}$ \\
\hline TIMP-1 & $\begin{array}{l}\text { Forward: ACTTCCACAGGTCCCACAAC } \\
\text { Reverse: AGCCACGAAACTGCAGGTAG }\end{array}$ \\
\hline TIMP-2 & $\begin{array}{l}\text { Forward: CCGCTCAAATACCTTCACAAT } \\
\text { Reverse: TTACGGCAGCAAGTCCAATA }\end{array}$ \\
\hline
\end{tabular}

resolved by $10 \%$ SDS-PAGE containing $0.1 \%$ gelatin after A549 cells were treated with various concentrations $(0,2.5,10$ and $25 \mathrm{mg} / \mathrm{ml}$ ) Angelica sinensis for $24 \mathrm{~h}$. After electrophoresis, gels were washed with distilled water containing $2.5 \%$ Triton X-100, then incubated in reaction buffer $(50 \mathrm{mmol} / \mathrm{l}$ Tris- $\mathrm{HCl}, 5 \mathrm{mmol} / \mathrm{CaCl}_{2}, 1 \mu \mathrm{mol} / 1 \mathrm{ZnCl}_{2}$ and $0.02 \% \mathrm{Brij}-35$ ) for $48 \mathrm{~h}$ at $37^{\circ} \mathrm{C}$. Then the gels were stained with Coomassie brilliant blue R-250. Non-staining bands representing the levels of the latent form of MMP-2 and MMP-9 were quantified by densitometer measurement using a digital imaging analysis system (GeneGenius, Syngene, UK).

SYBR-Green real-time quantitative PCR. We examined the effects of Angelica sinensis on expression of TGF- $\beta 1, \mathrm{MMP}$ and TIMP mRNA in A549 cells using SYBR-Green realtime quantitative PCR. A549 cells were treated with various concentrations $(0,2.5,10$ and $25 \mathrm{mg} / \mathrm{ml})$ of Angelica sinensis for $24 \mathrm{~h}$. Total RNA was extracted from the cells using an TRIzol Reagent (Toyobo, Japan) according to the manufacturer's instructions. The complementary DNA (cDNA) was produced from the extracted total RNA using a Reverse Transcriptase kit (Toyobo). Primer sequences are shown in Table I. Quantitative real-time PCR was performed using SYBR-Green PCR master mix (Toyobo) on the sequence detection system (Stratagene Mx3000p, USA), and the fluorescence was collected thrice during each cycle as described below. PCR was performed at $95^{\circ} \mathrm{C}$ for $15 \mathrm{sec}, 58^{\circ} \mathrm{C}$ for $15 \mathrm{sec}$, and $72^{\circ} \mathrm{C}$ for $15 \mathrm{sec}$ for 40 cycles. All the samples were run in triplicates, $\beta$-actin was used as an internal control in each run. Results of the real-time PCR were expressed as $C_{t}, C_{t}$ is the cycle number at which amplification fluorescence reaches a value above a preset threshold. The gene expression was measured by relative quantitative $2^{-\Delta \Delta \mathrm{Ct}}$ method (25). $\Delta \mathrm{C}_{\mathrm{t}}=\mathrm{C}_{\mathrm{t}}$ value of target- $\mathrm{C}_{\mathrm{t}}$ value of $\beta$-actin; $\Delta \Delta \mathrm{C}_{\mathrm{t}}=$ $\Delta \mathrm{C}_{\mathrm{t}}$ value of target group $-\Delta \mathrm{C}_{\mathrm{t}}$ value of untreated control group, the expression of the untreated control was $1,2^{-\Delta \Delta \mathrm{Ct}}$ value is the section of the treated group for control group.

Western blot analysis. A549 lung cancer cells were treated with different concentrations of Angelica sinensis for $24 \mathrm{~h}$, the

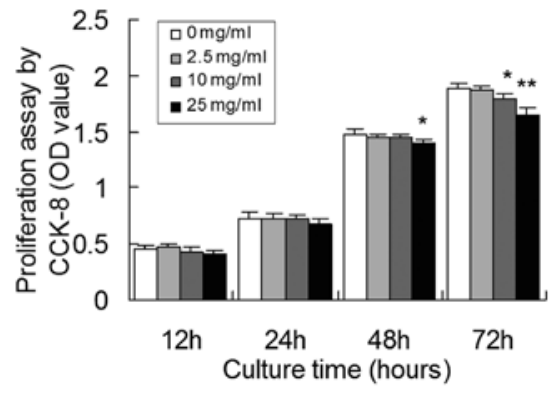

Figure 1. Effect of Angelica sinensis on the proliferation of A549 cells. The cells $\left(2 \times 10^{4}\right.$ cells $\left./ \mathrm{ml}\right)$ were treated with various concentrations $(0,2.5,5$ and $10 \mathrm{mg} / \mathrm{ml}$ ) of Angelica sinensis for 12, 24, 48 and $72 \mathrm{~h}$. Cell viability was determined by CCK- 8 assay. The surviving cell number was directly proportional to that of formazan, which was measured with microplate reader at $450 \mathrm{~nm}$. Each point was expressed at the mean \pm SD from six different experiments. $\left({ }^{*} \mathrm{P}<0.05,{ }^{* *} \mathrm{P}<0.001\right.$ compared to the untreated control at the same periods of time).

cells were harvested, and cellular proteins were extracted with lysis buffer. Total protein was separated by $12 \%$ SDS-PAGE and transferred to nitrocellulose membranes. After blocking with $5 \%$ non-fat dry milk, membranes were incubated with the primary antibodies of TGF- $\beta 1$, MMP-2 and MMP-9 (Biomeda Corp., Foster City, CA) overnight at $4^{\circ} \mathrm{C}$. The membranes were incubated with the appropriate peroxidase-conjugated secondary antibodies, and detected with ECL reagent. Protein levels were quantitated by a digital imaging analysis system (GeneGenius).

ELISA. TGF- $\beta 1$, MMP-2, MMP-9, TIMP-1 and TIMP-2 in conditioned medium was measured by ELISA kit (R\&D Systems) following the manufacturer's protocol. A549 cells were seeded at a density of $2 \times 10^{4}$ cells/well in a 96 -well plate for $24 \mathrm{~h}$, cells were treated with various concentrations $(0$, 2.5, 10 and $25 \mathrm{mg} / \mathrm{ml}$ ) Angelica sinensis for $24 \mathrm{~h}$. The culture media were collected at the end of incubation. The samples were added to each well of ELISA kit and incubated for $2 \mathrm{~h}$ at $37^{\circ} \mathrm{C}$. The detection antibody $50 \mu \mathrm{l}$ was added and incubated for $1 \mathrm{~h}$ at $37^{\circ} \mathrm{C}$. The working dilution of streptavidin $100 \mu \mathrm{l}$ was added to each well and incubated for $60 \mathrm{~min}$ at $37^{\circ} \mathrm{C}$. The substrate solution $50 \mu \mathrm{l}$ was added and incubated for 5-10 min at $37^{\circ} \mathrm{C}$. After the addition of stop solution, the optical density of each well was measured immediately with a microplate reader set to $492 \mathrm{~nm}$.

Statistical analysis. Values are expressed as means \pm SD of three independent experiments and a two-sample Student's t-test was performed to compare the treated groups with untreated control. Values of $\mathrm{P}<0.05$ were regarded as statistically significant.

\section{Results}

Effects of Angelica sinensis on the viability of A549 cells. In this study, we examined the effects of Angelica sinensis on the proliferation of A549 cells using the CCK-8 assay. The A549 cells were treated with Angelica sinensis at various concentrations $(0,2.5,10$ and $25 \mathrm{mg} / \mathrm{ml})$ for 12 , 24, 48 and $72 \mathrm{~h}$. Comparing to that of control (untreated 


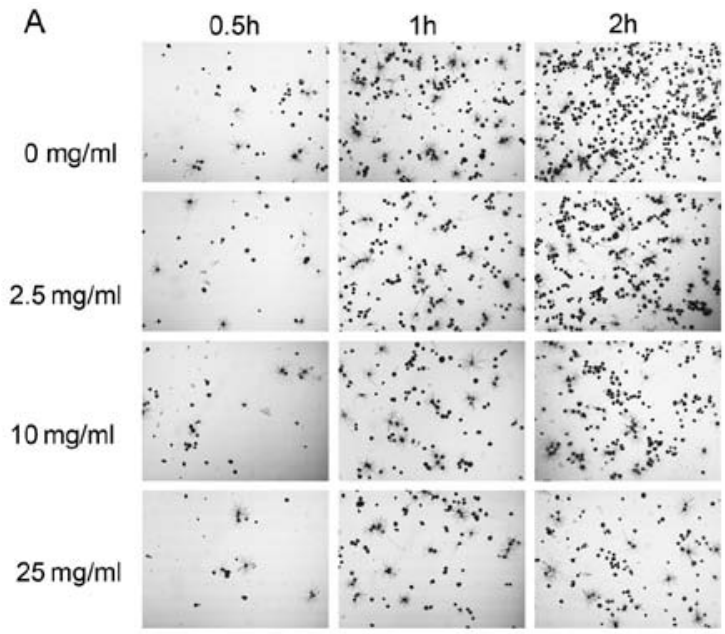

B

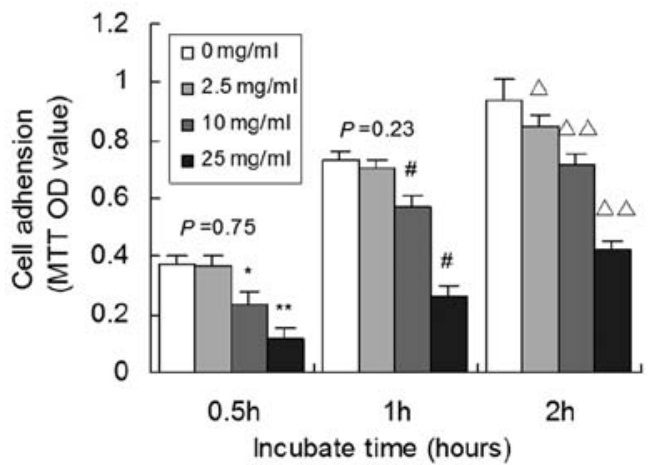

Figure 2. Inhibitory effects of Angelica sinensis on the cell-fibronectin adhesion of A549 cells. The cells $\left(4 \times 10^{4}\right)$ were added to a 96-well plate coated with $0.1 \%$ fibronectin before the cells were treated with various concentrations of Angelica sinensis $(0,2.5,10 \mathrm{and} 25 \mathrm{mg} / \mathrm{ml})$ for $24 \mathrm{~h}$, and the cells were incubated at 0.5 -h, 1-h and 2-h intervals. (A) The cells adhered to the well (x20 fold magnification). (B) The number of attached cells were calculated by the MTT assay. Result showed Angelica sinensis inhibit the cell-fibronectin adhesion. Values are expressed as the mean \pm SD of three independent experiments. ("P $<0.05$, ${ }^{* *} \mathrm{P}<0.001$ compared to the untreated control at $0.5 \mathrm{~h} ;{ }^{*} \mathrm{P}<0.001$ compared to the untreated control at $1 \mathrm{~h} ;{ }^{\Delta} \mathrm{P}<0.05,{ }^{\triangle \Delta} \mathrm{P}<0.001$ compared to the untreated control at $2 \mathrm{~h}$.

A

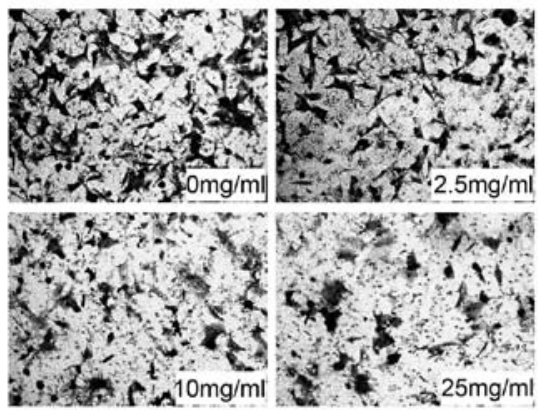

C

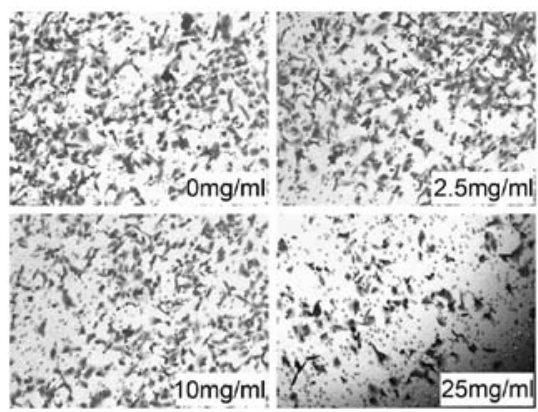

B

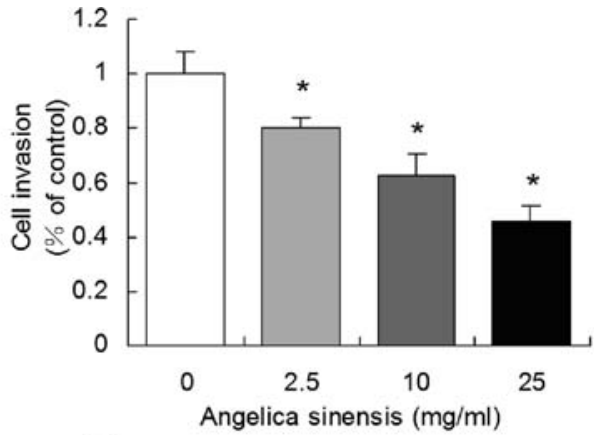

D

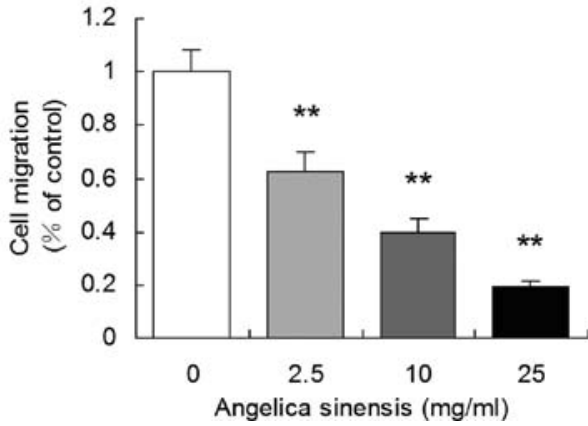

Figure 3. Inhibitory effects of Angelica sinensis on the invasion and migration of A549 cells. (A and C) Images of the invasion (200-fold magnification) and migration (100-fold magnification) were taken under a microscope. (B and D) The number of transwell invasion cells and migration cells were calculated, untreated control were taken as $100 \%$. The invasive and motility potentials of A549 cells were significantly inhibited by Angelica sinensis. Values are expressed as mean \pm SD of three independent experiments. $\left({ }^{*} \mathrm{P}<0.05,{ }^{* *} \mathrm{P}<0.001\right.$ compared to the untreated control).

with Angelica sinensis), the viability of A549 cells was not significantly affected at the dosage $2.5 \mathrm{mg} / \mathrm{ml}$ (Fig. 1). At the period of $48 \mathrm{~h}$, we observed weak growth inhibition even at the maximum concentration of $25 \mathrm{mg} / \mathrm{ml}$, the values were not much greater than those observed for the untreated control. It appears that Angelica sinensis requires $>25 \mathrm{mg} / \mathrm{ml}$ and $48 \mathrm{~h}$ to affect A549 cell proliferation. These results imply that multistep molecular events are necessary for function of Angelica sinensis to switch the A549 cells from a proliferative state to an inhibited state of cell growth.
Angelica sinensis inhibits adhesion, invasion and migration of A549 cells. Cell-fibronectin adhesion, cell invasion and cell motility are important for cancer cell metastasis. To examine the potential anti-metastasis effects of Angelica sinensis on A549 cells, we examined the effects of Angelica sinensis on the cell-fibronectin adhesion using the MTT assay. The results showed that at the dosage of $2.5 \mathrm{mg} / \mathrm{ml}$, Angelica sinensis has no obvious anti-adhesion effect to A549 cells at 0.5 -h and 1-h intervals. On the contrary, at the dosage 10 and $25 \mathrm{mg} / \mathrm{ml}$, we observed a significant anti-adhesion effect at all intervals. It 
Table II. Effects of Angelica sinensis on tumor metastasis to the lung in a mouse model.

\begin{tabular}{lccc}
\hline Groups & No. of mice & $\begin{array}{c}\text { No. of metastatic } \\
\text { nodules }\end{array}$ & $\begin{array}{c}\text { Weight of } \\
\text { lungs }(\mathrm{mg})\end{array}$ \\
\hline Control $(\mathrm{mg} / \mathrm{g})$ & 8 & $124 \pm 27$ & $220.8 \pm 9.3$ \\
0.5 & 8 & $117 \pm 30$ & $212.3 \pm 5.6$ \\
1 & 8 & $82 \pm 17^{\mathrm{a}}$ & $197.1 \pm 6.0^{\mathrm{b}}$ \\
5 & 8 & $58 \pm 21^{\mathrm{b}}$ & $176.3 \pm 6.7^{\mathrm{b}}$ \\
\hline
\end{tabular}

Effect of Angelica sinensis on lung metastasis of nude mice was determined as described in the text. The mice were sacrificed 14 days after cell injection, and the number of lung metastasis and the whole lung weight were measured. Lung metastatic nodules $>0.5 \mathrm{~mm}$ in diameter were counted. The results indicate the mean \pm SD from three independent preparations. Statistically significant value compared with untreated control ( $\left.{ }^{\mathrm{a}} \mathrm{P}<0.05,{ }^{\mathrm{b}} \mathrm{P}<0.001\right)$.

appears that Angelica sinensis requires $>2.5 \mathrm{mg} / \mathrm{ml}$ to significantly affect A549 cell adhesion (Fig. 2). We examined the effects of Angelica sinensis on invasion and migration of A549 cells using a cell invasion and migration assay with the transwell chamber. The results showed Angelica sinensis induced a dose-dependent decrease in invasion and migration with an increasing concentration of Angelica sinensis. The invasive activities of A549 cells were significantly $(\mathrm{P}<0.05)$ reduced to $63 \%$ by treatment of $10 \mathrm{mg} / \mathrm{ml}$ Angelica sinensis, and reduced to $46 \%$ by treatment of $25 \mathrm{mg} / \mathrm{ml}$ Angelica sinensis (Fig. 3A and B). The migrative activities of A549 cells were significantly $(\mathrm{P}<0.001)$ reduced to $40 \%$ by treatment of $10 \mathrm{mg} / \mathrm{ml}$ Angelica sinensis, and to $19 \%$ of $25 \mathrm{mg} / \mathrm{ml}$ Angelica sinensis compared to untreated group (Fig. 3C and D). The results demonstrated that Angelica sinensis significantly inhibited the invasion and migration of highly metastatic A549 lung cancer cells.

Effects of Angelica sinensis on tumor metastasis to the lung in a mouse model. The studies described above clearly showed that Angelica sinensis has a potent ability to inhibit the metastasis of A549 cells in vitro. To investigate the role of Angelica sinensis in metastasis in vivo, we used an animal model to analyze the metastatic potential of A549 cells. In the model, the highly metastatic A549 cells were injected into the tail vein of nude mice, the mice were treated with Angelica sinensis $(0.5,1$ and $5 \mathrm{mg} / \mathrm{g})$ p.i. three times a week for 14 days. When the mice were treated with $0.5 \mathrm{mg} / \mathrm{g}$ Angelica sinensis p.i. there was no obvious difference of metastatic colonies and the weights of lung compare with the untreated control $(\mathrm{P}=0.53, \mathrm{P}=0.25)$. But lung metastasis and weights were significantly decreased when the concentration of Angelica sinensis was increased to $5 \mathrm{mg} / \mathrm{g}$ suggesting Angelica sinensis reduced the metastatic ability only at high concentration. This experiment was performed three times with similar results (Table II).

Angelica sinensis inhibits the MMP-2 and MMP-9 activities of A549 cells. To examine the possible anti-metastatic mechanisms of Angelica sinensis, we determined the activity of MMP-2 and MMP-9 in culture media of A549 cells by
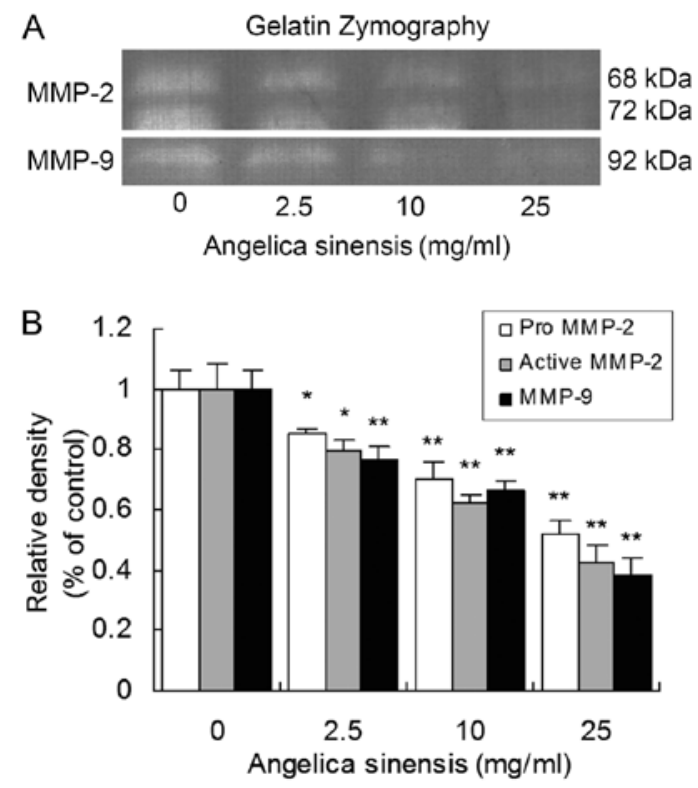

Figure 4. Angelica sinensis inhibits MMP-2 and MM-9 activity. MMP-2 and MMP-9 activities were determined by gelatin zymography. (A) The 68- and 72-kDa bands may correspond to active and latent MMP-2 forms. (B) MMP-2 and MMP-9 activities were quantified by densitometric analysis. Angelica sinensis reduced MMP-2 and MMP-9 activity in a dose-dependent manner. Results are the mean \pm SD from three independent preparations $\left({ }^{*} \mathrm{P}<0.05\right.$, ${ }^{* *} \mathrm{P}<0.01$ compared to the untreated control).

zymographic analysis. The result showed MMP-2 and MMP-9 activity were suppressed in a dose-dependent manner by treatment of Angelica sinensis $(0,2.5,10$ and $25 \mathrm{mg} / \mathrm{ml})$. The active MMP-2 activity was reduced to $62 \%(\mathrm{P}<0.01)$ by treatment of $10 \mathrm{mg} / \mathrm{ml}$ Angelica sinensis, and reduced to $42 \%(\mathrm{P}<0.01)$ by treatment of $25 \mathrm{mg} / \mathrm{ml}$ Angelica sinensis compared with untreated group. The MMP-9 activity was reduced to $66 \%(\mathrm{P}<0.01)$ by treatment of $10 \mathrm{mg} / \mathrm{ml}$ Angelica sinensis, and reduced to $38 \%(\mathrm{P}<0.01)$ by treatment of $25 \mathrm{mg} / \mathrm{ml}$ Angelica sinensis compare with untreated group (Fig. 4). These results suggest that the anti-metastatic effect of Angelica sinensis is related to inhibition of the enzyme activity of MMP-2 and MMP-9.

Angelica sinensis regulates MMP-2 and MMP-9 levels. To investigate whether the metastasis inhibitory effect of Angelica sinensis resulted from the suppression of MMP-2 and MMP-9 expression, MMP-2 and MMP-9 protein and mRNA levels were measured. The protein levels from wholecell lysates of MMP-2 and MMP-9 were assessed using Western blotting (Fig. 5A and B), and the protein levels in the culture medium was measured by an ELISA (Fig. 5C and D), respectively. The intracellular protein levels of MMP-2 and MMP-9 by Western blotting decreased to $26 \%(\mathrm{P}<0.01)$ and $44 \%(\mathrm{P}<0.01)$, and extracellular protein levels of MMP-2 and MMP-9 by an ELISA decreased to $43 \%(\mathrm{P}<0.01)$ and $37 \%(\mathrm{P}<0.01)$ after treatment of $25 \mathrm{mg} / \mathrm{ml}$ Angelica sinensis. Quantitative real-time PCR with SYBR-Green (Fig. 5E) was further employed to analyze the effect of Angelica sinensis on the mRNA transcriptional expression of MMP-2 and MMP-9. The mRNA expression of MMP-2 and MMP-9 also decreased in a dose-dependent manner. The changes in the protein levels 
A

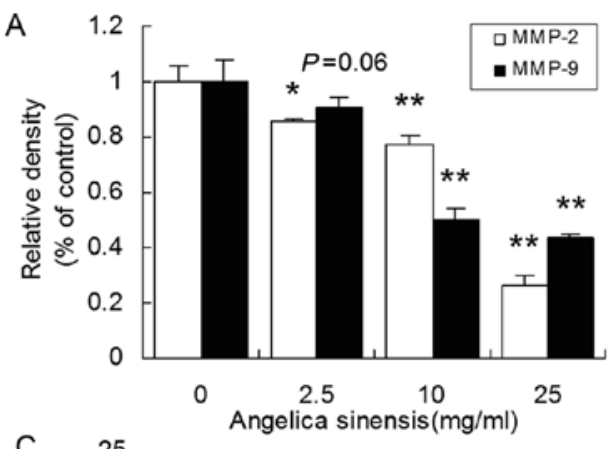

C

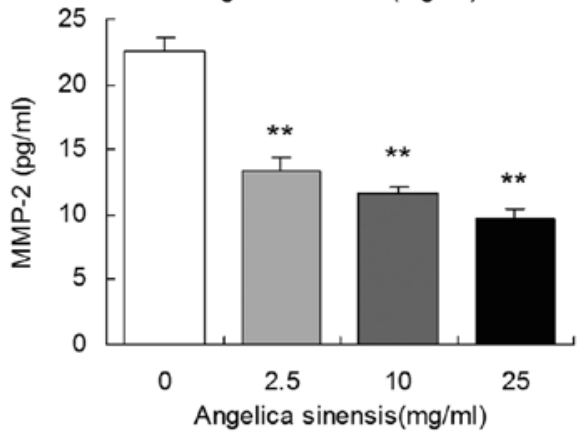

B

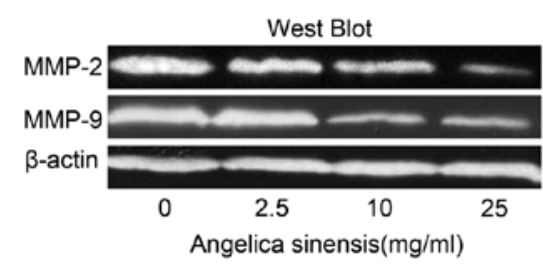

D

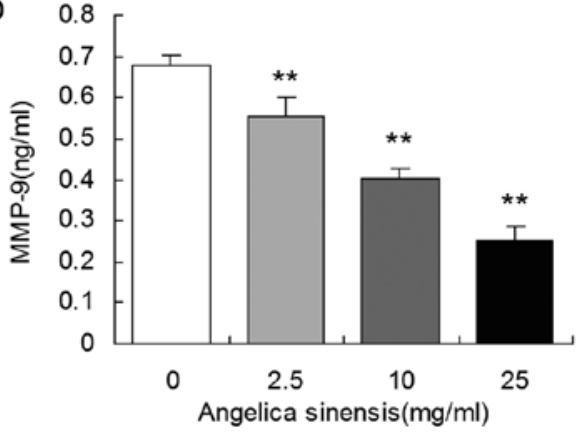

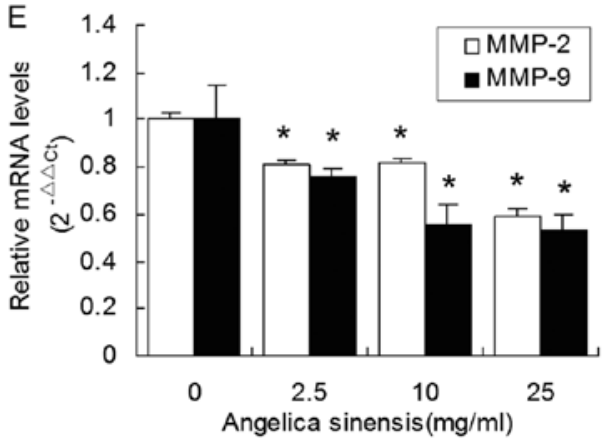

Figure 5. Angelica sinensis inhibits MMP-2 and MMP-9 protein and mRNA levels. (A) MMP-2 and MMP-9 protein levels were quantified by densitometric analysis. (B) Western blot analysis of MMP-2 and MMP-9. (C and D) MMP-2 and MMP-9 concentration in the culture medium was measured by ELISA. (E) Relative mRNA levels of MMP-2 and MMP-9 were quantitated by real-time SYBR-Green PCR and the $2^{-\Delta \Delta C t}$ method. The expression of the untreated control was $1,2^{-\Delta \Delta C t}$ value is the section of the treated group for control group. Angelica sinensis reduced MMP-2 and MMP-9 protein and mRNA expression. The results indicate the mean \pm SD from three independent preparations. Statistically significant value compared to untreated control $\left({ }^{*} \mathrm{P}<0.05,{ }^{* * *} \mathrm{P}<0.01\right.$ compared to untreated control).

of MMP-2 and MMP-9 coincided with their mRNA levels, indicating that Angelica sinensis might regulate MMP-2 and MMP-9 expressions at the transcriptional level.

Angelica sinensis increase levels of TIMP-2 but decrease levels of TIMP-1. Activity of MMP-2 and MMP-9 are significantly related to their inhibition of TIMPs, especially TIMP-1 and TIMP-2. In order to further relate the regulatory effects of Angelica sinensis on inhibitor of MMP-2 and MMP-9, the expression of TIMP-1 and TIMP-2 mRNA and protein levels were measured (Fig. 6). The result showed Angelica sinensis obviously increased mRNA and protein levels of TIMP-2, the mRNA expression of TIMP-2 increased to 2.4-fold even at the lowest dose $2.5 \mathrm{mg} / \mathrm{ml}$, and protein levels of TIMP-2 increased to 1.7 -fold by treatment of $2.5 \mathrm{mg} / \mathrm{ml}$ Angelica sinensis. The increasing secretion of TIMP-2 resulted in the inhibition of MMP-2 and MMP-9 activity as assessed by zymographic analysis (Fig. 5A and B). In contrast to TIMP-2, TIMP-1 decreased significantly in three experiment groups $(\mathrm{P}<0.05)$. TIMP-1 mRNA reduced to $76 \%$ and protein levels of TIMP-1 reduced to $50 \%$ by treatment of $25-\mathrm{mg} / \mathrm{ml}$ Angelica sinensis. These results suggest that Angelica sinensis inhibition of the enzyme activity of MMPs (especially MMP-2) is related to the increase of TIMP-2 but not TIMP-1.

Angelica sinensis inhibits the TGF- $\beta 1$ expression of A549 cells. TGF- $\beta$ promotes tumor progression through the up-regulation of matrix metalloproteinase MMP-2 and MMP-9. We investigated whether the MMP-2 and MMP-9 inhibitory effect of Angelica sinensis resulted from the suppression of TGF- $\beta 1$ expression, TGF- $\beta 1$ mRNA and protein levels were measured. The protein levels from whole-cell lysates of TGF- $\beta 1$ were assessed using Western blotting, the protein levels in the culture medium was measured by ELISA. The intracellular and extracellular protein levels of TGF- $\beta 1$ all decreased in a dose-dependent manner. The mRNA expression of TGF- $\beta 1$ also decreased in a dose-dependent manner. Angelica sinensis inhibited the TGF- $\beta 1$ expression of A549 cells, the MMP-2 and MMP-9 inhibitory effect of Angelica sinensis is probably through regulation of TGF- $\beta 1$ expression (Fig. 7). 

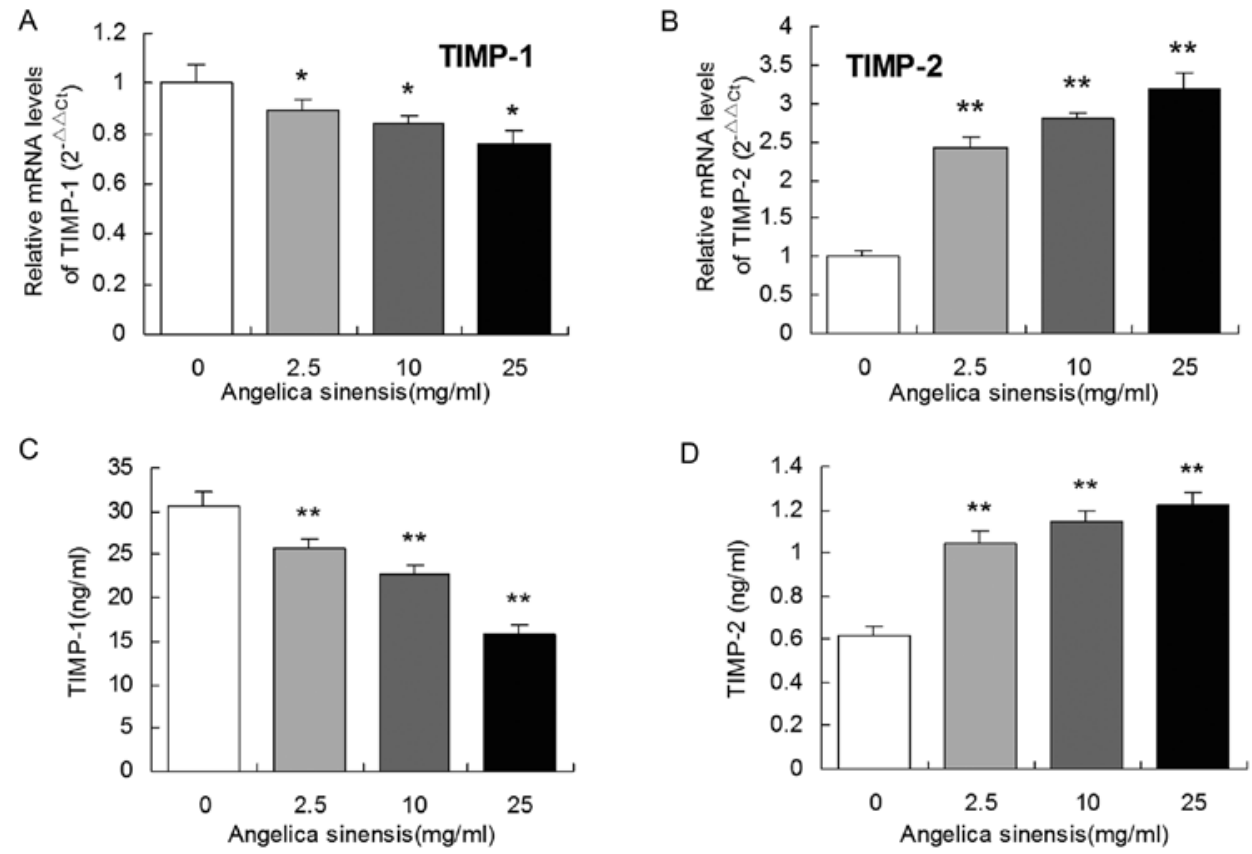

Figure 6. Effect of Angelica sinensis on TIMP-1 and TIMP-2 expressions in A549 cells. (A and B) The relative mRNA levels of TIMP-1 and TIMP-2 were quantitated by real-time SYBR-Green PCR and the $2^{-\Delta \Delta C t}$ method. (C and D) TIMP-1 and TIMP-2 concentration in the culture medium was measured by an ELISA kit as described in Materials and methods. Angelica sinensis reduced TIMP-1 but increased TIMP-2 mRNA and protein expression. The results are the mean \pm SD from three independent preparations. $\left({ }^{*} \mathrm{P}<0.05,{ }^{* *} \mathrm{P}<0.001\right.$ compared to untreated control).

A

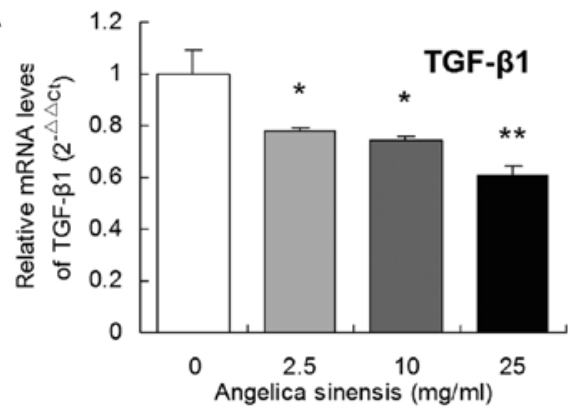

B

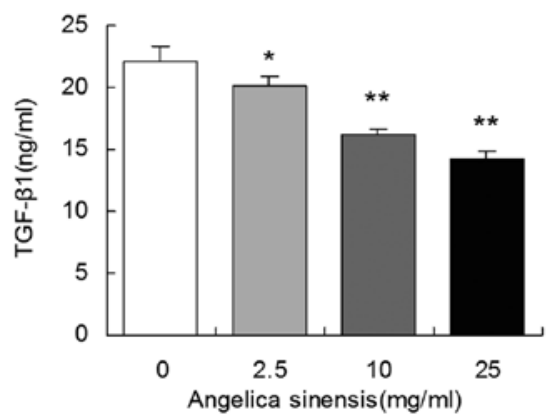

C

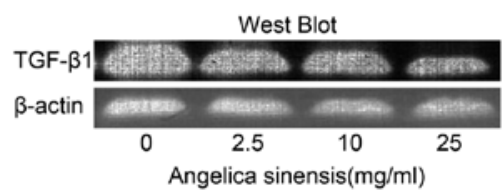

D

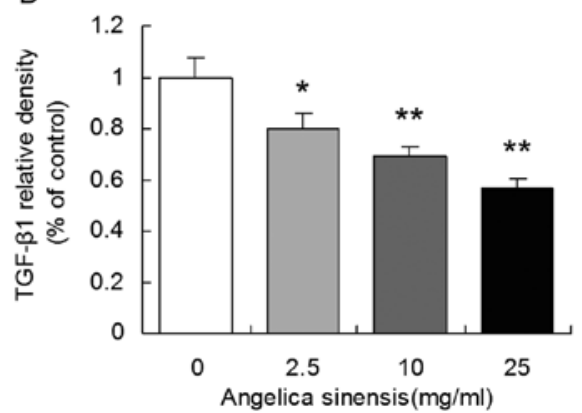

Figure 7. Angelica sinensis inhibits TGF- $\beta 1 \mathrm{mRNA}$ and protein levels. (A) Relative mRNA levels of TGF- $\beta 1$ were quantitated by real-time SYBR-Green and the $2^{-\Delta \Delta C t}$ method. The expression of the untreated control was $1,2^{-\Delta \Delta C t}$ value is the section of the treated group for control group. (B) TGF- $\beta 1$ concentration in the culture medium was measured by an ELISA kit. (C) The protein levels of TGF- $\beta 1$ from whole-cell lysates were measured by Western blot analysis $\beta$-actin served as an internal control. (D) TGF- $\beta 1$ were quantified by densitometric analysis. Angelica sinensis inhibits TGF- $\beta 1 \mathrm{mRNA}$ and protein expression. The results are the mean \pm SD from three independent preparations. $\left(" \mathrm{P}<0.05,{ }^{* * *} \mathrm{P}<0.01\right.$ compared to the untreated control).

\section{Discussion}

The root of Angelica sinensis, also known as 'Danggui' has been a popular herbal medicine and widely used for a long time in China. Various extracts from Angelica sinensis were found to have many functions including increasing myocardial ischemia, reduce radiation damages and liver injury, it has also been widely used for treat anemia, thrombosis, and atherosclerosis (26-32).

It has been reported that extracts of Angelica sinensis could inhibit the growth of tumor cells (33-40). But, Lau et al found the water extract of Angelica sinensis stimulated the growth of 
MCF-7 cells (41). In this study, Angelica sinensis did not show significant cytotoxicity on A549 cells, but when interacted with A549 cells for $>48 \mathrm{~h}$ at $25 \mathrm{mg} / \mathrm{ml}$, Angelica sinensis weakly inhibited the growth of A549 cells. Our results agree with the vast majority. Lau et al considered that the water extract of Angelica sinensis stimulated the growth of MCF-7 cells, possibly dependent of weak estrogen-agonistic activity. Thus suggesting caution in use of Angelica sinensis in women with breast cancer, but it is safe for long-term use in lung cancer patient specially at high concentration.

Tumor metastasis occurs by a series of steps including cell attachment, invasion, and cell proliferation, and is regulated by extremely complicated mechanisms (42). To examine the potential anti-metastasis effects of Angelica sinensis, adhesion, invasion and migration assays were performed on A549 cells. Angelica sinensis inhibited the adhesion of A549 cells to $0.1 \%$ fibronectin, one of the ECM components as well as effectively suppressed the invasion and migration of A549 cells in a concentration-dependent manner suggesting Angelica sinensis cannot promote tumor metastasis, but can inhibit tumor cell invasion and metastasis capacity.

Tumor invasion and metastasis require degradation of ECM, and increased expression of proteases associated with these processes. To understand how Angelica sinensis inhibited A549 cell metastasis, we focused on Angelica sinensis altered proteinases MMP-2 and MMP-9 which are believed to play a critical role in tumor invasiveness and metastasis. We demonstrated that Angelica sinensis suppresses the mRNA expression, protein synthesis and activation of MMP-2 and MMP-9 by A549 cells in a dose- and time-dependent manner. We also showed that Angelica sinensis inhibited invasion of A549 cells in a dose-dependent manner, indicating that the inhibition of MMP-2 and MMP-9 function resulted in the loss of ability for A549 cells to degrade the component of Matrigel and thus the ability to invade in vitro.

Another possible anti-metastatic mechanism of Angelica sinensis is through increased expression of TIMP-2. TIMPs are endogenous inhibitors that can block the activities of MMPs. The balance between the levels of activated MMPs and free TIMPs determines overall MMP activity. The overexpression of TIMPs has been demonstrated to reduce experimental metastasis. TIMP-1 and TIMP-2 were known to have a particularly high affinity for MMP-9 and MMP-2, respectively (43). Many studies have found that TIMP-2 overexpression decreased invasion of endothelial and tumor cells both in vitro and in vivo $(44,45)$. This study showed Angelica sinensis obviously increased TIMP-2 expression but decreased TIMP-1 expression, which can inhibit the enzyme activity of MMP-2 and MMP-9.

Angelica sinensis expression inhibits cancer proliferation possibly by inhibiting the TIMP-1. Although it has been reported that TIMP-1 acts as a metastasis suppressor gene, some studies have shown increased expression of TIMP-1 in tumor cells in accordance with the poorer results $(46,47)$. TIMP-1 promotes cell growth $(48,49)$ and inhibits apoptosis $(50,51)$. It was shown recently that TIMP-1 contributes functionally to neoplastic development in a mouse model of epithelial carcinogenesis (52). Angelica sinensis inhibits the TGF- $\beta 1$ expression of A549 cells. TGF- $\beta 1$ has been shown in several studies of nephropathy to increase the expression of TIMP-1 (53-56), the TIMP-1 inhibitory effect of Angelica sinensis is probably through regulation of TGF- $\beta 1$ expression.

In conclusion, the present study demonstrates that Angelica sinensis significantly inhibits the metastasis ability of human lung cancer A549 cells. The proposed anti-invasion mechanisms might be mediated through the inhibition of MMP-2 and MMP-9, TGF- $\beta 1$ and TIMP-1, as well as enhancement of TIMP-2. Further analysis with semi-quantitative RT-PCR showed that the regulation of MMP-2, MMP-9 and TIMP-2 expressions by Angelica sinensis may be on the transcriptional level.

\section{Acknowledgements}

This study was supported by grants from Torch-plan Foundation of Hubei Province of China.

\section{References}

1. Claude L, Pérol D, Ginestet C, et al: A prospective study on radiation pneumonitis following conformal radiation therapy in non-small cell lung cancer: clinical and dosimetric factors analysis. Radiother Oncol 71: 175-181, 2004.

2. Guo GS and Wang H: Effect of angelica sinensis on fibroblast in bleomycin induced pulmonary fibrosis in rats. Wu Han Da Xue Xue Ba (Yi Xue Ban) 28: 560-563, 2007.

3. Liu WM, Xu QY, Lin YH, Ye YQ, Dai L and Liu YL: Study of influence of $25 \%$ angelica injection to bleomycin-induced pulmonary fibrosis. Wu Han Da Xue Xue Ba (Yi Xue Ban) 22: 325-327, 2001.

4. Zhong YH, Han G, Zhou YF, Peng M, Xie CH, Zhou FX and Zhang WJ: Protection of Angelica sinensis against radiationinduced pulmonary fibrosis in mice. Zhonghua Yu Fang Yi Xue Za Zhi 2: 105-109, 2007.

5. Li XT, Wang YQ and Fu Nw: Effect of some drugs of promoting blood circulation and removing blood stasis on the pulmonary metastases of mouse hepatoma cells. J Trad Chinese Med 8: 75-77, 1980.

6. Han JQ, Chen YT, Man YY, et al: Clinical study on effect of combined treatment of fuchunpian with radiotherapy on nasopharyngeal carcinoma. Zhongguo Zhong Xi Yi Jie He Za Zhi 15: 710-712, 1995

7. Yu JG, Hu SK, Li XL, et al: The effect of paeonia rubba 801 on the occurrence of lung metastasis in Walker 256 tumou. Chin J Cancer Res 5: 226-234, 1993.

8. Parks WC and Shapiro SD: Matrix metalloproteinases in lung biology. Respir Res 2: 10-9, 2001.

9. Stamenkovic I: Extracellular matrix remodelling: the role of matrix metalloproteinases. J Pathol 200: 448-464, 2003.

10. Brown PD, Bloxidge RE, Stuart NS, Gatter KC and Carmichael J: Association between expression of activated 72-kilodalton gelatinase and tumor spread in non-small cell lung carcinoma. J Natl Cancer Inst 85: 574-578, 1993.

11. González-Avila G, Iturria C, Vadillo F, Terán L, Selman M and Pérez-Tamayo R: 72-kD (MMP-2) and 92-kD (MMP-9) type IV collagenase production and activity in different histologic types of lung cancer cells. Pathobiology 66: 5-16, 1998.

12. Urbanski SJ, Edwards DR, Maitland A, Leco KJ, Watson A and Kossakowska AE: Expression of metalloproteinases and their inhibitors in primary pulmonary carcinomas. Br J Cancer 66: 1188-1194, 1992.

13. Mackay AR, Corbitt RH, Hartzler JL and Thorgeirsson UP: Basement membrane type IV collagen degradation: evidence for the involvement of a proteolytic cascade independent of metalloproteinases. Cancer Res 50: 5997-6001, 1990.

14. Kodate M, Kasai T, Hashimoto H, Yasumoto K, Iwata Y and Manabe $\mathrm{H}$ : Expression of matrix metalloproteinase (gelatinase) in T1 adenocarcinoma of the lung. Pathol Int 47: 461-469, 1997.

15. Ray JM and Stetler-Stevenson WG: The role of matrix metalloproteases and their inhibitors in tumour invasion, metastasis and angiogenesis. Eur Respir J 7: 2062-2072, 1994. 
16. Apte SS, Olsen BR and Murphy G: The gene structure of tissue inhibitor of metalloproteinases (TIMP) -3 and its inhibitory activities define the distinct TIMP gene family. J Biol Chem 270 : 14313-14318, 1995.

17. Goldberg GI, Strongin A, Collier IE, Genrich LT and Marmer BL: Interaction of 92-kDa type IV collagenase with the tissue inhibitor of metalloproteinases prevents dimerization complex formation with interstitial collagenase, and activation of the proenzyme with stromelysin. J Biol Chem 267: 4583-4591, 1992.

18. Brew K, Dinakarpandian D and Nagase H: Tissue inhibitors of metalloproteinases: evolution, structure and function. Biochim Biophys Acta 1477: 267-283, 2000.

19. Nelson AR, Fingleton B, Rothenberg ML and Matrisian LM: Matrix metalloproteinases: biologic activity and clinical implications. J Clin Oncol 18: 1135-1149, 2000.

20. Deryugina EI and Quigley JP: Matrix metalloproteinases and tumor metastasis. Cancer Metastasis Rev 25: 9-34, 2006.

21. Wiercinska E, Naber HP, Pardali E, van der Pluijm G, van Dam $\mathrm{H}$ and Ten Dijke P: The TGF- $\beta /$ Smad pathway induces breast cancer cell invasion through the up-regulation of matrix metalloproteinase 2 and 9 in a spheroid invasion model system. Breast Cancer Res Treat 128: 657-666, 2011.

22. Bruna A, Darken RS, Rojo F, et al: High TGFbeta-Smad activity confers poor prognosis in glioma patients and promotes cell proliferation depending on the methylation of the PDGF-B gene. Cancer Cell 11: 147-160, 2007.

23. Han G, Zhou YF, Zhang MS, et al: Angelica sinensis downregulates hydroxyproline and Tgfb1 and provides protection in mice with radiation-induced pulmonary fibrosis. Radiat Res 165: 546-552, 2006

24. Xie CH, Zhang MS, Zhou YF, et al: Chinese medicine Angelica sinensis suppresses radiation-induced expression of TNF-alpha and TGF-beta1 in mice. Oncol Rep 15: 1429-1436, 2006.

25. Livak KJ and Schmittgen TD: Analysis of relative gene expression data using real-time quantitative PCR and the $2^{-\Delta \Delta C t}$ method. Methods 25: 402-408, 2001.

26. Zhang S, He B, Ge J, et al: Extraction, chemical analysis of Angelica sinensis polysaccharides and antioxidant activity of the polysaccharides in ischemia-reperfusion rats. Int $\mathrm{J}$ Biol Macromol 47: 546-550, 2010.

27. Kim SH, Lee SE, Oh H, et al: The radioprotective effects of bu-zhong-yi-qi-tang: a prescription of traditional Chinese medicine. A J Chin Med 30: 127-137, 2002.

28. Yu F: Protective effects of Angelica sinensis polysaccharide on immunological liver injury induced by con-canavalin $\mathrm{A}$ in mice. Zhong Yao Cai 32: 1580-1583, 2009.

29. Ye YN, Liu ES, Li Y, et al: Protective effect of polysaccharidesenriched fraction from Angelica sinensis on hepatic injury. Life Sci 69: 637-646, 2001

30. Liu PJ, Hsieh WT, Huang SH, Liao HF and Chiang BH: Hematopoietic effect of water-soluble polysaccharides from Angelica sinensis on mice with acute blood loss. Exp Hematol 38: 437-445, 2010

31. Zhang L, Du JR, Wang J, Yu DK, Chen YS, He Y and Wang CY: Z-ligustilide extracted from Radix Angelica Sinensis decreased platelet aggregation induced by ADP ex vivo and arterio-venous shunt thrombosis in vivo in rats. Yakugaku Zasshi 129: 855-859, 2009.

32. Hou YZ, Zhao GR, Yang J, Yuan YJ, Zhu GG and Hiltunen R: Protective effect of Ligusticum chuanxiong and Angelica sinensis on endothelial cell damage induced by hydrogen peroxide. Life Sci 75: 1775-1786, 2004.

33. Cao W, Li XQ, Wang X, et al: A novel polysaccharide, isolated from Angelica sinensis (Oliv.) Diels induces the apoptosis of cervical cancer HeLa cells through an intrinsic apoptotic pathway. Phytomedicine 17: 598-605, 2010.

34. Cao W, Li XQ, Wang X, Li T, Chen X, Liu SB and Mei QB Characterizations and anti-tumor activities of three acidic polysaccharides from Angelica sinensis (Oliv.) Diels. Int J Biol Macromol 46: 115-122, 2010.

35. Kan WL, Cho CH, Rudd JA and Lin G: Study of the anti-proliferative effects and synergy of phthalides from Angelica sinensis on colon cancer cells. J Ethnopharmacol 120: 36-43, 2008.
36. Cao W, Li XQ, Hou Y, Fan HT, Zhang XN and Mei QB: Structural analysis and anti-tumor activity in vivo of polysaccharide APS-2a from Angelica sinensis. Zhong Yao Cai 31: 261-266, 2008.

37. Tsai NM, Chen YL, Lee CC, et al: The natural compound n-butylidenephthalide derived from Angelica sinensis inhibits malignant brain tumor growth in vitro and in vivo. J Neurochem 99: 1251-1262, 2006.

38. Tsai NM, Lin SZ, Lee CC, et al: The antitumor effects of Angelica sinensis on malignant brain tumors in vitro and in vivo. Clin Cancer Res 11: 3475-3484, 2005.

39. Cheng YL, Chang WL, Lee SC, et al: Acetone extract of Angelica sinensis inhibits proliferation of human cancer cells via inducing cell cycle arrest and apoptosis. Life Sci 75: 1579-1594, 2004.

40. Shang P, Qian AR, Yang TH, et al: Experimental study of antitumor effects of polysaccharides from Angelica sinensis. World J Gastroenterol 9: 1963-1967, 2003.

41. Lau CB, Ho TC, Chan TW and Kim SC: Use of dong quai (Angelica sinensis) to treat peri- or postmenopausal symptoms in women with breast cancer: is it appropriate? Menopause 12: 734-740, 2005

42. Fidler IJ: The organ microenvironment and cancer metastasis. Differentiation 70: 498-505, 2005.

43. Joo YE, Seo YH, Lee WS, et al: Expression of tissue inhibitors of metalloproteinases (TIMPs) in hepatocellular carcinoma. Korean J Intern Med 15: 171-178, 2000

44. Kim MH, Bodenstine TM, Sumerel LA, Rivera AA, Baker AH and Douglas JT: Tissue inhibitor of metalloproteinases-2 improves antitumor efficacy of a replicating adenovirus in vivo. Cancer Biol Ther 5: 1647-1653, 2006.

45. Simeone AM, McMurtry V, Nieves-Alicea R, Saavedra JE, Keefer LK, Johnson MM and Tari AM: TIMP-2 mediates the anti-invasive effects of the nitric oxide-releasing prodrug JS-K in breast cancer cells. Breast Cancer Res 10: R44, 2008.

46. Gouyer V, Conti M, Devos P, et al: Tissue inhibitor of metalloproteinase-1 is an independent predictor of prognosis in patients with non-small cell lung carcinoma who undergo resection with curativeintent. Cancer 103: 1676-1684, 2005.

47. Aljada IS, Ramnath N, Donohue K, et al: Upregulation of the tissue inhibitor of metalloproteinase-1 protein is associated with progression of human non-small cell lung cancer. J Clin Oncol 22: 3218-3229, 2004

48. Bertaux B, Hornebeck W, Eisen AZ and Dubertret L: Growth stimulation of human keratinocytes by tissue inhibitor of metalloproteinases. J Invest Dermatol 97: 679-685, 1991.

49. Hayakawa T, Yamashita K, Tanzawa K, Uchijima E and Iwata K: Growth-promoting activity of tissue inhibitor of metalloproteinases-1 (TIMP-1) for a wide range of cells. A possible new growth factor in serum. FEBS Lett 298: 29-32, 1992.

50. Guedez L, Stetler-Stevenson WG, Wolff L, Wang J, Fukushima P, Mansoor A and Stetler-Stevenson M: In vitro suppression of programmed cell death of B cells by tissue inhibitor of metalloproteinases-1. J Clin Invest 102: 2002-2010, 1998.

51. Li G, Fridman R and Kim HR: Tissue inhibitor of metalloproteinase-1 inhibits apoptosis of human breast epithelial cells. Cancer Res 59: 6267-6275, 1999.

52. Rhee JS, Diaz R, Korets L, Hodgson JG and Coussens LM: TIMP-1 alters susceptibility to carcinogenesis. Cancer Res 64: 952-961, 2004

53. Mo W, Brecklin C, Garber SL, et al: Changes in collagenase and TGF- $\beta$ precede structural alterations in a model of chronic renal fibrosis. Kidney Int 56: 145-153, 1999.

54. Leehey DJ, Song RH, Alavi N and Singh AK: Decreased degradative enzymes in mesangial cells cultured in high glucose media. Diabetes 44: 929-935, 1995.

55. Death AK, Yue DK and Turtle JR: Competitive RT-PCR for measuring metalloproteinase gene expression in humanmesangial cells exposed to a hyperglycemic environment. Biotechniques 27: 512-518, 1999.

56. Abdel Wahab N and Mason RM: Modulation of neutral protease expression in human mesangial cells by hyperglycaemic culture. Biochem J 320: 777-783, 1996. 